\title{
PENINGKATAN TINGKAT PENGETAHUAN ANGGOTA KELUARGA TERKAIT BAHAYA MEROKOK DAN HUBUNGANNYA DENGAN HIPERTENSI MELALUI PENYULUHAN KESEHATAN
}

\author{
Tantri Puspita ${ }^{1}$, Muhammad Hadi Sulhan², Lisna Latifah ${ }^{3}$, Neng Rohimah ${ }^{4}$, Devita \\ Arumandana $^{5}$, Manarul Taufik ${ }^{6}$, Karlina ${ }^{7}$ \\ ${ }^{1}$ Prodi Profesi Ners, STIKes Karsa Husada Garut \\ ${ }^{2}$ Prodi Analis Kesehatan, STIKes Karsa Husada Garut \\ 3,4,5,6,7 Mahasiswa Prodi Profesi Ners, STIKes Karsa Husada Garut \\ J1. Nusa Indah No.24, Jayaraga, Tarogong Kidul, Kabupaten Garut, Jawa Barat 44151 \\ e-mail: tanpus1987@gmail.com
}

\begin{abstract}
ABSTRAK
Pendahuluan: hipertensi merupakan penyakit tidak menular yang angkanya terus meningkat. Hipertensi disebabkan oleh banyak faktor. Salah satunya adalah merokok. Efek dari kebiasaan merokok ini dirasakan Pada seluruh rentang kehidupan, dari masa janin sampai usia lanjut. Meskipun mengetahui merokok itu tidak baik bagi kesehatan, tetapi masih banyak penderita hipertensi yang tidak bisa berhenti merokok. Penyuluhan kesehatan merupakan salah satu metode untuk meningkatkan kesadaran kesehatan dari sisi pengetahuan. Kegiatan ini bertujuan untuk meningkatkan pengetahuan anggota keluarga terkait efek rokok pada penyakit hipertensi yang diderita. Metode: penyluhan keehatan ini menggunakan Liquid Crystal Display (LCD), laptop dan diakhiri dengan pemberian leaflet penyuluhan yang diberikan kepada kepada anggota keluarga yang memiliki hipertensi dengan kebiasaan merokok. Keluarga atau perwakilannya di kumpulkan di sebuah madrasah yang telah disepakati bersama. Hasil: kegiatan penyuluhan menunjukan bahwa sebagian besar peserta yang hadir adalah perempuan sejumlah 18 orang $(72 \%)$ dan lebih dari sepertiganya peserta adalah perokok pasif (80\%). Pada segi pengetahuan, tampak adanya perubahan level yang pada awalnya $80 \%$ berada pada level kurang, $10 \%$ masing-masing berada pada level cukup dan tinggi berubah menjadi 15\% responden berada pada level pengetahuan cukup dan 85\% berada pada level tinggi. Kesimpulan: Diharapkan kepada pihak terkait, terutama tenaga kesehatan terutama dari Puskesmas Garawangsa dapat melanjutkan kegiatan peningkatan pengetahuan kepada masyarakat terkait hipertensi. Sehingga bertambah tingkat pengetahuan masyarakat. Sehingga kejadian kematian dan kesakitan dari penyakit ini dapat dicegah melalui kegiatan penyuluhan kesehatan.
\end{abstract}

\section{Kata Kunci : Penyuluhan Kesehatan, hipertensi, merokok}

\begin{abstract}
Introduction: hypertension is a non-communicable disease which the rate are increased. Hypertension caused by many factors. One of them is smoking. The effects of smoking are felt by all life spans, fetuses to the elderly. Even though smoking is not good for health, there are still many hypertension sufferers who cannot stop to smoke. Health education is one method to increase health awareness in terms of knowledge. Method: Using the Liquid Crystal Display (LCD), laptop and closed by giving leaflets to the family members who have hypertension with smoking habits. Families or representatives are collected in a place that has been mutually agreed upon. Results: the health education activity showed that the majority of participants who were present were 18 women (72\%) and more than one third of the participants were passive smokers (80\%). In terms of knowledge, it was appeared that there was a change in level that initially $80 \%$ were at the low level, $10 \%$ each at a moderate level and high. It was changed to $15 \%$ of respondents were at the moderate level and $85 \%$ were at a high level of knowledge. Conclusion: It is expected that related parties, especially health workers in Garawangsa Health Community Center can continue their knowledge-raising activities to the community related to hypertension. Thus this can increase the level of knowledge of the community. Thus, the incidence of the morbidity and mortality from this disease can be prevented through health education activities.
\end{abstract}

Key Words : Health education, hypertension, smoking 


\section{PENDAHULUAN}

Merokok menjadi salah satu penyebab tingginya angka kesakitan dan kematian terbesar di United Kingdom. Angka kematiannya bisa mencapai puluhan ribu per tahun dan kesakitannya lebih dari 50 penyakit kronis (NHS UK, 2018). Hal ini terjadi tidak hanya pada perokok pasif tapi juga perokok aktif. Selain itu, efek asap rokok dapat juga dirasakan dan berpengaruh pada kesehatan janin sampai dengan lansia (CDC, 2018).

Tidak jauh berbeda dengan UK, angka kematian dan kesakitan akibat merokok juga tinggi di Indonesia. Menurut Kemenkes RI, (2019). Tercatat lebih dari 200 ribu kematian pertahun disebabkan oleh kebiasaan merokok. Angka kejadian penyakit kanker paru yang penyebab utamanya adalah merokok, menempati urutan pertama dibandingkan dengan penyakit lain di RS umum Persahabatan Jakarta. Yang menghawatirkan, prevalensi kebiasan merokok usia remaja telah mengalami peningkatan hampir 10\%.

Kejadian kesakitan pada perokok menyerang pada organ-organ penting seperti pada sistem pencernaan, pernafasan dan kardiovaskuler. Pada organ pencernaan, kebiasaan merokok dapat meyebabkan penyakit pada mulut, tenggorokan dan pita suara. Pada sistem pernafasan dapat menyebabkan penyakit paru obstruksi kronis (PPOK), bronkhitis dan emfisema. Sedangkan pada sistem kardiovaskuler, merokok dapat mengganggu organ jantung dan sistem peredaran darah (CDC, 2018).

Khusus pada sistem peredaran darah, CDC (2018) menjelaskan bahwa merokok dapat menyebabkan kerusakan pembuluh darah. Hal ini disebabkan karena kondisi pembuluh darah menjadi menebal dan bertambah sempit. Sehingga denyut nadi menjadi cepat serta tekanan darah menjadi meningkat. Virdis, Giannarelli, Neves, Taddei, dan Ghiodani (2010) menjelaskan bahwa tidak ditemukan adanya perbaikan berupa penurunan tekanan darah pada perokok meskipun telah berhenti merokok. Merokok telah mengakibatkan kekakuan pada arteri pembuluh darah dan efek merugikan pada tekanan darah pusat akibat percepatan terjadinya aterosklerosis.

Hasil pendataan mahasiswa Praktik Profesi STIKes Karsa Husada Garut angkatan ke-9 di Kampung Peer Desa Linggamukti Kecamatan Garawangsa menunjukan bahwa dari 233 kepala keluarga, ada 215 yang memiliki anggota keluarga yang merokok. Selain itu, ditemukan ada 18 orang warganya yang lansia menderita penyakit kardiovaskuler seperti darah tinggi dan stroke.

Sebuah perilaku dan sikap kesehatan, dapat dipengaruhi oleh tingkat pengetahuan seseorang. Beberapa penelitian di Indonesia menunjukan bahwa pendidikan kesehatan berperan penting untuk meningkatkan pengetahuan. Beberapa penelitian di Indonesia menunjukan keefektifan pemberian pendidikan kesehatan pada perubahan tingkat pengetahuan pesertanya. Seperti penelitian oleh Febriyanto (2016) menunjukan adanya hubungan yang signifikan antara pengetahuan, sikap dan perilaku murid pada pemilihan jajanan sehat di Sekolah Madrasah Ibtidaiyah (MI) Sulaimaniyah Kecamatan Mojoagung Kabupaten Jombang. Selain itu, Fauzian, Rahmi dan Nugroho (2016) menjelaskan ahwa semakin tinggi pengetahuan pasien pada penyakit glaukoma, semakin baik perilaku pasien tersebut dalam memeriksaan diri ke pelayanan kesehatan di Rumah Sakit. Nafisah et., al. (2019) menjelaskan bahwa health promotion berbentuk penyuluhan kesehatan efektif untuk meningkatkan pengetahuan ibu berusia 35 sampai 
dengan 49 tahun dengan anak penderita infeksi pernafasan.

Tidak hanya pada sisi pengetahuan, beberapa penelitian menunjukan bahwa sikap dan perilaku kesehatan dapat berubah dan mengalami peningkatan setelah diberikan intervensi berupa penyuluhan kesehatan (Fastring, Johnson dan Madison, 2017; Bisallah et., al, 2018; Wang et., al, 2018). Di malaysia, penyuluhan kesehatan efektif untuk meningkakan pengetahuan dan sikap pada pemeriksaan kanker serviks dan tindakan pap smear (Romli, Shahabudin, Saddki, dan Mokhtar, 2020). Tidak berbeda dengan Penelitian tersebut, Kaushal, Singh, Pada dan Deepti (2018), menemukan bahwa ada perubahan tingkat pengetahuan, sikap dan perilaku pada 155 guru sekolah lanjutan pertama terkait kesehatan fisik dan psikososial seperti perubahan masa pubertas, peningkatan tinggi dan berat badan, kebutuhan kalori dan protein, efek konsumsi junk food, upaya kesehatan sekolah serta penyalahgunaan obat pada remaja di India.

Dengan demikian, perlu diadakannya pengabdian masyarakat terkait penyakit hipertensi berfokus pada kebiasaan merokok dengan melakukan penyuluhan kesehatan di kampung Peer Desa Linggamukti Kecamatan Garawangsa Wilayah Kerja Puskesmas Garawangsa.

\section{METODE}

Alat dan bahan yang digunakan dalam penyuluhan ini adalah laptop, Liquid Crystal Display (LCD), pengeras suara dan leaflet (lihat tabel 1).
Tabel 1. Alat dan Bahan Pendidikan Kesehatan Bahaya Merokok dan Hipertensi di Wilayah Kerja Puskesmas Garawangsa

\begin{tabular}{lll}
\hline No & Alat dan Bahan & $\mathrm{N}$ \\
\hline 1. & LCD & 1 \\
2. & Leaflet & 30 \\
3. & Laptop & 2 \\
4. & Pengeras suara & 1 \\
\hline
\end{tabular}

Adapun langkah langkah yang telah dilakukan untuk melaksanakan kegiatan ini adalah: tim penyuluhan melakukan sosialisasi kepada tokoh masyarakat dan sekaligus meminta ijin untuk dilakukan kegiatan penyuluhan kesehatan. Setelah ijin diperoleh, tim penyuluhan melakukan sosialisasi dan kontrak waktu dengan keluarga terkait pelaksanaan kegiatan.

\section{HASIL dan PEMBAHASAN}

Kegiatan Penyuluhan ini dilaksanakan tanggal 22 November 2019 dari pukul 19.00-21.00. Kegiatan ini terlaksana dengan baik berkat dukungan semua pihak. Baik dari Puskesmas Garawangsa Kab. Garut, Kepala Desa, $\mathrm{RT} / \mathrm{RW}$ dan warga masyarakat setempat. Kegiatan dilakukan pada malam hari dikarenakan kegiatan warga yang tidak ada di rumah saat siang hari terutama warga yang bekerja di ladang/sawah ataupun sebagai buruh harian, sehingga waktu malam hari dipilih sebagai waktu yang tepat. Kegiatan penyuluhan ini merupakan implementasi dari kesepakatan bersama pihak terkait dari masalah-masalah kesehatan yang muncul setelah proses pendataan dan analisa bersama pihak terkait.

Acara dimulai dengan pengisian daftar hadir kemudian sambutan dari perwakilan Puskesmas dan Bapak RT kampung Peer Desa Linggamukti. Sebelum penyampaian materi, pre-test dilakukan untuk mengetahui kebiasaan merokok (aktif atau pasif) peserta yang hadir serta tingkat level pengetahuan terkait materi yang akan disampaikan. 
Setelah pre-test dilakukan, materi disampaian selama satu (1) jam termasuk tanya jawab dan terakhir post-test terkait tingkat pengetahuan peserta setelah dilakukan penyuluhan. Setelah post-test dilakukan, leaflet yang telah disediakan dibagikan kepada peserta yang datang.

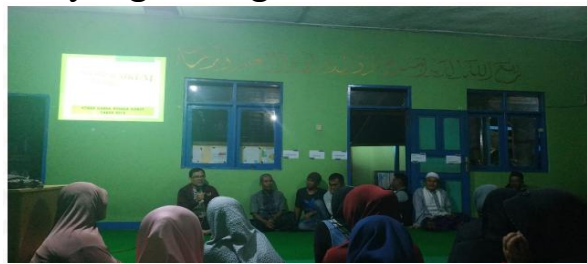

Gambar 1. Sambutan Perwakilan Puskesmas

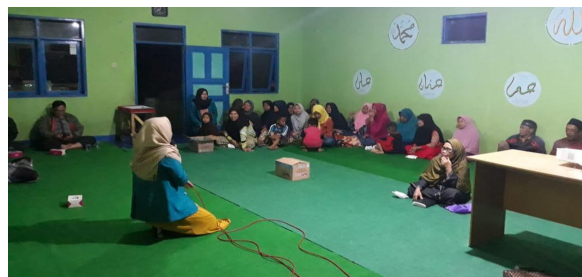

Gambar 2. Kegiatan Penyuluhan

Berikut gambaran karakteristik peserta yang hadir pada acara tersebut.

Tabel 2. Jumlah Peserta Pendidikan Kesehatan Bahaya Merokok dan Hipertensi Berdasarkan Jenis Kelamin di Wilayah Kerja Puskesmas Garawangsa

\begin{tabular}{lll}
\hline No & Jenis kelamin & Jumlah \\
\hline 1 & Laki-laki & 7 \\
2 & Perempuan & 18 \\
\hline
\end{tabular}

Dari tabel 2 di atas, diketahui bahwa jumlah yang hadir sebagian besar adalah perempuan sejumlah 18 orang $(72 \%)$ dan sebagian kecil adalah laki-laki sejumlah 7 orang (28\%). Dari sisi jenis kelamin, pada penyuluhan kesehatan ini ditemukan bahwa jumah seluruh perokok aktif merupakan laki-laki. Hal ini sesuai dengan data yang tercantum pada penelitian Widianti dan Wahyono (2014) yang menemukan bahwa responden penelitiannya di sebuah SMP negeri di Kota Bogor menunjukan bahwa jumlah responden siswa perokok laki-laki lebih besar daripada siswa perempuan $\quad(38,1$ dan $12,4 \%$ masing-masing). Data Kemenkes RI
(2018) menunjukan bahwa perokok di Indonesia didominasi oleh laki-laki. Meskipun sebagian kecilnya berjenis kelamin perempuan. Jumlah ini terus bertambah dari tahun 1995 sampai 2013. Jenis kelamin laki-laki lebih cenderung mendominasi menjadi perokok aktif dikarenakan norma-norma yang ada dimasyarakat dimanipulasi dan dieksploitasi oleh pihak industri yang memposisikan bahwa penggunaan tembakau dikaitkan bersifat kemaskulinan (WHO, 2018).

Jenis kelamin pada remaja membedakan awal mula seseorang untuk merokok. Pada remaja putri, umumnya merokok merupakan sebuah alasan untuk mengontrol berat badan. Di negara maju, remaja putri merokok erat kaitannya dengan kondisi kepribadian berupa harga diri yang rendah. Meskipun di beda tempat, kebiasaan merokok sangat dipengaruhi oleh aspek budaya, kondisi psikososial dan sosial ekonomi yang ada (WHO, 2010). Seperti dijelaskan oleh Chinwong, Mookmanee, Chongpornchai dan Chinwong (2018) yang menemukan bahwa perokok jenis kelamin laki-laki lebih banyak daripada wanita. Hal tersebut dikarenakan adanya penolakan bersifat sosial dan kepercayaan bahwa laki-laki perokok tampak lebih atraktif dibanding perempuan. Selain itu, laki-laki perokok lebih bisa diterima oleh orang tua/wali dibandingkan perempuan.

Berikut jumlah peserta yang hadir berdasarkan kebiasaan merokok

Tabel 3. Jumlah peserta Penyuluhan berdasarkan kebiasaan merokok pada penyuluhan kesehatan bahaya merokok dan Hipertensi di Wilayah Kerja Puskesmas Garawangsa

\begin{tabular}{lll}
\hline No & Kebiasaan merokok & Jumlah \\
\hline 1 & Aktif & 5 \\
2 & Pasif & 20 \\
\hline
\end{tabular}

Tabel 3 di atas menunjukan bahwa $80 \%$ peserta adalah perokok pasif yang 
diperoleh dari anggota keluarganya, sedangkan $20 \%$ sisanya (5 orang) adalah perokok aktif. Dari perokok aktif tersebut, seluruhnya berjenis kelamin laki-laki.

Pendataan dari peserta penyuluhan pada tabel 3, diketahui bahwa semua yang hadir adalah perokok, dimana sebagian besarnya adalah perokok pasif. Dikategorikan sebagai perokok pasif, karena seluruh peserta pernah terpapar asap rokok dari perokok aktif yang tinggal serumah dengan mereka. Seperti dijelaskan oleh Kemenkes RI (2018) bahwa menjadi perokok pasif pada individu di Indonesia bisa diperoleh dari berbagai tempat, baik tempat umum maupun privat. Salah satunya tempat terpaparnya perokok pasif adalah di tempat kerja, restoran, kendaraan umum. Sedangkan pada remaja, terpapar asap rokok dapat terjadi di lingkungan pergaulan (Widianti \& Wahyono 2014) atau anggota keluarga perokok aktif yang tinggal serumah untuk paparan pada anggota keluarga yang lain terutama pada balita (Sihombing \& Notohartojo, 2015).

Efek paparan asap rokok berbeda pada perokok aktif dan perokok pasif. Sebuah sistematik review oleh Aryanpur, et., al, (2019) menunjukan bahwa paparan aktif asap rokok (perokok aktif) tidak ada kaitannya dengan perkembangan hipertensi pada anak-anak dan dewasa. Namun, jika paparan ini terjadi pada masa kandungan atau saat masih janin, erat kaitannya dengan kejadian peningkatan tekanan darah sistolik pada masa itu. Di sisi lain, efek negatif merokok pada kejadian hipertensi lebih dirasakan oleh mereka yang berusia di atas 35 tahun dibanding usia yang lebih muda. Hal ini terjadi dapat disebabkan karena adanya perbedaan jumlah dan durasi penggunaan rokok serta keterbatasan artikel penelitian yang ditemukan. Data dari Park et., al, (2018) mennunjukan bahwa hasil survey pada 8987 wanita yang tidak pernah merokok tahun 2010-2012 yang berusia lebih dari 20 tahun menunjukan adanya hubungan yang signifikan antara terpapar asap rokok secara pasif dengan kejadian hipertensi.

Hasil gambaran pengetahuan peserta penyuluhan sebelum dan sesudah dilakukan penyuluhan kesehatan tentang bahaya merokok dan hipertensi

Tabel 4. Tingkat Pengetahuan Peserta Penyuluhan Bahaya Merokok dan Hipertensi di Wilayah Kerja Puskesmas Garawangsa

\begin{tabular}{llll}
\hline No & $\begin{array}{l}\text { Tingkat } \\
\text { pengetahuan }\end{array}$ & $\begin{array}{l}\text { Sebelum } \mathrm{n} \\
(\%)\end{array}$ & $\begin{array}{l}\text { Sesudah } \\
\mathrm{n}(\%)\end{array}$ \\
\hline 1 & Kurang & 80 & - \\
2 & Cukup & 10 & 15 \\
3 & Tinggi & 10 & 85 \\
\hline
\end{tabular}

Tabel 4 di atas menunjukan adanya perubahan tingkat pengetahuan peserta sebelum dan sesudah dilakukan penyuluhan. Dari semua yang hadir, peserta menunjukan adanya peningkatan pengetahuan dari $80 \%$ berada pada level kurang, 10\% masing-masing berada pada level cukup dan tinggi, mengalami perubahan menjadi $15 \%$ berada pada level cukup dan $85 \%$ berada pada level tinggi.

Pada sisi pengetahuan, peserta penyuluhan menunjukan adanya adanya perubahan level tingkat pengetahuan setelah diberikan penyuluhan. Penelitian di beberapa negara menunjukan adanya perubahan yang signifikan pemberian penyuluhan kesehatan pada tingkat pengetahuan pesertanya.

Penelitian oleh Wang et., al, (2018) menunjukan adanya perbedaan tingkat pengetahuan pada kelompok intervensi dibandingkan kelompok kontrol murid tingkat dasar, sekolah lanjutan pertama, dan sekolah menengah akhir di wilayah Gansu, China terkait pengetahuan pada penyakit infeksius. Namun, perhatian yang khusus dan lebih perlu diperhatikan pada peserta kaum minoritas, tinggal di pedesaan/kampung/wiayah tertinggal, 
dan berjenis kelamin laki-laki. Penelitian lain oleh Bisallah et., al (2018) juga menunjukan bahwa terdapat perbedaan tingkat pengetahuan penderita $\mathrm{TB}$ penderita HIV di Minna, Nigeria. Dimana, kelompok intervensi menunjukan tingkat pengetahuan lebih tinggi daripada kelompok kontrol setelah 3,6 dan 9 bulan dilakukan intervensi berupa penyuluhan kesehatan.

\section{KESIMPULAN DAN SARAN}

Kegiatan penyuluhan ini merupakan bagian dari kegiatan pengabdian masyarakat dosen prodi profesi ners dan analis kesehatan beserta mahasiswa kepada masyarakat di Kampung Peer Desa Linggamukti wilayah kerja Puskesmas Garawangsa Kabupaten Garut. Kegiatan berupa pemberian penyuluhan kepada perwakilan keluarga dengan anggota keluarga perokok aktif maupun pasif. Hasil kegiatan penyuluhan diketahui dapat meningkatkan tingkat pengetahuan peserta menjadi cukup dan tinggi. Dengan demikian diharapkan pihak terkait seperti Puskesmas dapat menindaklanjuti kegiatan tersebut dengan selalu memberikan arahan dan bimbingan kepada warga dalam pencegahan penyakit tidak menular seperti hipertensi untuk pencegahan kesakitan dan kematian akibat penyakitpenyakit tersebut di masyarakat.

\section{UCAPAN TERIMA KASIH}

Puji dan syukur kami haturkan kepada Tuhan YME dan semua pihak yang telah membantu terlaksananya kegiatan pengabdian masyarakat ini yaitu Puskesmas Garawangsa sebagai penanggung jawab wilayah kesehatan Desa Linggamukti, Kepala Desa Linggamukti, Bapak/Ibu RT dan RW di Kampung Peer serta tokoh masyarakat lainnya. Selain itu, kami ucapkan terima kasih pula kepada STIKes Karsa Husada Garut yang telah memfasilitasi dan mendorong diadakannya kegiatan penyuluhan ini.

\section{DAFTAR PUSTAKA}

Aryanpur, M., Yousefifard, M., Oraii, A., Heydari, G., Kazempor-Dizaji, M., Shrifi, H., Hosseini, M dan Jamaati, H. (2019). Effect of passive exposure to cigarette smoke on blood pressure in children and adolescents: a meta-analysis of epidemic studies. BMC pediatric 19:161.

Bisallah, C. I., Rampal, L., Lye. M.S., Sidik, S.M., Ibrahim, N., Illyasu, Z., Onyilo, M.O. (2018). Effectiveness of health education intervention in Improving knowledge, attitude and practices regarding tuberculosis among HIV patients in General Hospital Minna, Nigeria-A randomized control trial. PLoS ONE 13(2): e0192276. https://doi.org/10.1371/journal.pon e. 0192276

CDC. (Januari 2018). Health effect of cigarette smoking. Retrieved from https://www.cdc.gov/tobacco/data statistics/fact_sheets/health_effects /effects cig_smoking/index.htm\#c ardio

Chinwong, D., Mookmanee, Ng., Chongpornchai, J. Dan Chinwong, S. (2018). A comparison og Gender differences in smoking behaviors, intention to quit and nicotine dependence among Thai University students. Hindawi Journal of Addiction. https://doi.org/10.1155/2018/8081 670

Fauzian, R.A., Rahmi, F.L., dan Nugoho, T. (2016). Huubungan tingkat pengetahuan dengan perilaku memeriksakan diri ke pelayanan kesehatan: Penelitian pada pasien glaukoma di rumah sakit DR. Kariadi. Jurnal kedokteran diponegoro 5 (1634-1641). Dari http://ejournal-s1.undip.ac.id 
Febriyanto, M.A.B. (2016). Hubungan antara pengetahuan dan sikap dengan perilaku konsumsi jajanann sehat di MI Sulaimaniyah Mojoagung Jombang. Universitas Airlangga. Dari jurnal. Um-surabaya.ac.id

Kaushal, P., Singh T, Padda A.S., dan Deppti, S.S. (2018). Effectiveness of a health education intervention on the knowledge, attitude and practices of teachers regarding physical and psychosocial health of adolescents in Amitsar, Punjab. International Journal of Community Medicine and Public Health Kaushal $P$ et al. Int $J$ Community Med Public Health. 2018 Nov; 5(11):4921-4926

Kemenkes RI. (2018). Situasi umum konsumsi tembakau di Indonesia. Jakarta. Kemenkes RI.

Kemenkes RI. (Juli, 2019). HTTS 2019: jangan biarkan rokok merenggut nafas kita. Retrieved dari https://www.kemkes.go.id/article/v iew/19071100001/htts-2019-janga n-biarkan-rokok-merenggut-napaskita.html

Lu'lu Nafisah, Siti Herwanti, Dwi Annisa Fajria, Avi Nurdinia, Ajeng Prastiwi, Michika Adisa, Irfan Febriary, Nurul Akmalia, and Dilla Fadhilah, (2019), "The Effectiveness of Health Promotion on Knowledge of Mothers about Acute Respiratory Infections (ARI) in Mipiran Village, Padamara Public Health Center" in The 2nd International Meeting of Public Health 2016: Public Health Perspective of Sustainable Development Goals: Challenges and Opportunities in Asia Pacific Region, KnE Life Sciences, pages 123-128.

DOI

10.18502/kls.v4i10.3777

NHS UK. (Oktober, 2018). What are the heallth risk of smoking?. Retrieved from https://www.nhs.uk/common-healt h-questions/lifestyle/what-are-thehealth-risks-of-smoking/

Park YS, Lee C-H, Kim Y-I, et al. Association between secondhand smoke exposure and hypertension in never smokers: a crosssectional survey using data from Korean National Health and Nutritional Examination Survey V, 2010-2012. BMJ Open 2018;8:e021217. doi:10.1136/ bmjopen-2017-021217

Romli, R., Shahabudin S., Saddki, N., dan Mokhtar, N. (2020). Effectiveness of a health education program to improve knowledge and attitude towards cervical cancer and papsmear: a controlled community trial in malaysia. Asian Pac J Cancer 21 (3), 853-859. Doi: 10.31557/APJCP.2020.21.853

Sihombing, M., dan Notohartojo, I.T. (2015).

Gambaran sociodemografi perokok pasif dengan ISPA dan daktor yang berhubungan dengan kejadian ISPA pada balita di Indonesia (Analisis data riskesdas 2013). Badan penelitian dan pengembangan kesehatan Kemenkes RI. Diperoleh pada tanggal 25 April 2020. Dari id.portalgaruda.net

Wang,M., Han, X. Fang, H., Xu, C., Lin, X., Xia, S., Yu, W., He, J., Jiang, Sdan Tao, H. (2018). Impact of health eduation on knowledge and behaviors towards infectious diseases among students in Gansu Province, China. Biomed Research International. doi.org/10.1155/2018/6397340

WHO. (Juli 2018). Gender-responsive tobacco control: evidence and optiions for policies and programmes. Retrieved from https://www.who.int/fctc/cop/sessi ons/cop8/Gender-Responsive-Toba cco-Control.pdf 
Widianti, E.V., dan Wahyono, T.Y.M. (2014). Faktor-faktor yang berhubungan dengan perilaku merokok siswa SMP Negeri "X" di Kota Bogor tahun 2014. Departemen Kesehatan Reproduksi, Fakultas Kesehatan masyarakat Universitas Indonesia. Diperoleh pada tanggal 25 April 2020. Dari lib ui.ac.id

Virdis, A., Giannarelli, C., Neves, M.F., Taddei, S., dan Ghiodani L. (2010). Cigarette smoking and hypertension. Current Pharmaceutical Design, 16 (000-000). Doi: $10.2174 / 138161210792062920$ 